\title{
Solar Dryer Selection and its Applications for Various Household Items
}

\author{
Izhak Devid Paul $^{1}$, Dr. Adwait Manoharrao Vaidya ${ }^{2}$, Dr. Prajitsen G. Damale ${ }^{3}$, \\ ${ }^{1}$ Research Scholar, KBC North Maharashtra University, Jalgaon, India, Pin 425001 \\ ${ }^{2}$ Professor, Campus Director Mechanical Engineering Brahma Valley College of Engineering and Research Institute, \\ Nashik, India \\ ${ }^{3}$ Associate Professor, Mechanical Engineering SSBT's, College of Engineering, Bambhori, 425001, India
}

Received on: 16 July, 2021

Revised on: 15 August, 2021

Published on: 17 August, 2021

\begin{abstract}
Open sun drying is the oldest and method of drying which gives the trends to use fossil fuel dryers like electric dryers, wood dryers, and many more. This helps in drying the item quickly and more effectively but spoils the environment. To avoid such things solar dryer is needed. The solar dryer is available in many types its selection is important as per the application or items of drying. Selection of materials and cost estimation is discussing with the selection method. Then methods to predict the moisture contents are discussing and this helps to conclude that the solar dryer is more essential for household products.
\end{abstract}

Keywords- Solar Dryer, dehydration, application of dryer, selection of dryer, the scope of the dryer.

\section{I -INTRODUCTION}

F ood is the basic need of all human beings and to supply food for a long period is the biggest challenge. The quality and quantity both are important in food. Losses of fruits and vegetables are everywhere, most developing countries still facing this problem. About 30 to $40 \%$ of total production gets loss [1]. To protect fruits and vegetables from this loss it is important to remove the moisture present in the fruits and vegetables to a certain extent. The moisture removal can be done by open sun drying which is one the oldest method. Otherwise, fossil fuel dryers can be used for the same.
Many industries are using electricity, natural gas, biomass, and solar energy for drying foods [2,3]. There are different types of dryers and have their performance is differing as per the food and environment. The dryer can be used for many products like chilies, turmeric, peanut, grapes, copra, etc. the types of the dryer and possible improvement for better performance is studied [3]. Fossil fuels pollute the surroundings and not available in plenty. Solar energy is available free of cost and can be used for drying. Many researchers study solar energy and give their views by experimenting and reviewing the literature. Solar energy used by indirect solar dryer which is most prominently used by many researchers gives good quality products. Different techniques are incorporated for improving the performance of the dryer [4].

A new conception of the absorber in the collector of an indirect dryer is used for thermal storage of solar energy. Two corrugated aluminium plates are used in the collector which gives the thermal efficiency of $11.11 \%$ [5]. Different types of dryers discuss with application [6]. To use a dryer of one type doesn't provide high performance. A dryer with mixed-mode can give more efficiency than a single one. The efficiency of the dryer is mostly depending on the air temperature and its velocity, type of product solar radiation, and moisture content [7]. 


\section{International Journal of Innovations in Engineering and Science, www.ijies.net}

Nabnean design a parabolic shape flat plate collector cover with a polycarbonate plate. The dryer was so designed that it can dry the banana from $72 \%$ W.B.9wet basis to $28 \%$ w.b in 4 days [8].

A box-type solar dryer is designed to dry the mango slices under controlled and protected conditions. The time taken to dry the $100 \mathrm{~kg}$ of sliced mango is two days and moisture removal is from $81.4 \%$ to $10 \%$. The dryer area was only $1.03 \mathrm{~m}^{2}$ [9]. The design procedure with all mathematical terms and conditions is studied for designing a solar dryer of any type [10]. The solar dryer with a $1 \mathrm{~m}^{2}$ area can dry many products like chilies, bit root, potatoes, and many more. The box-type dried was instructed to dry $20 \mathrm{~kg}$ of fresh vegetables from $89.6 \%$ to $13 \%$ w.b [11]. The dryer of mix mode types gives more variants in the drying of food items than other types. The solar and wind energy combinations give the much easier and clean dryer [12]. A solar dryer can be made at a low cost and even cheap local material can be used to construct the dryer and this will be helpful to farmers and others also [13]. The solar dryer scope is not limited to the industries or agricultural land it can be used for household purposes also [14]. the dryer can be tested by many methods. The modelling techniques like CFD, ANFIS modelling, ANN modelling, fuzzy logic, and its application for understanding the drying concept [15]. There are various types of advancement are developed in the solar drying system [16].

The objective of this paper is to explain the importance of solar drying and its application for industries and household products. Its major application is in a household.

\section{II - METHODOLOGY}

\section{A. Selection of Dryer for Industry and Household}

1. Initial selection: - the first step is the type of solar dryer i.e. direct, indirect, mixed, or hybrid. The free convection or forced convection. The types should best suit the wet material and the continuity of the process.

2. Initial comparison: - the selected dryer in step 1 is needed to evaluate the cost, space, and performance.

3. Solar drying test: - now test the dryer selected according to steps $1 \& 2$ for small scale and concluded the result for alternatives experimental readings. Based on the result and conclusion made a design of dryers for said capacity, cost, operating cost, product quality, dryer operability, and available space.

4. Final selection of solar dryer: - based on step 3 final selection dryer is made for types and capacity.

The dryer can be select on the following points. i) Physical features - types, size, shape collector area.

ii) Thermal performance - solar insolation, drying time/drying rate, efficiency.

iii) Properties of material - physical characteristics, acidity, toxicity, etc.

iv) Drying characteristics of the material - the type of moisture (bound, unbound, or both), initial moisture, final moisture drying temperature.

v) The flow of material to and from the dryer Quantity to be handled per hour, continuous or batch operation, prior and post-process.

vi) Product qualities - Shrinkage, contamination, overdrying, appearance, flavour.

vii) Facilities were available at the site of proposed installation - space, Temperature, humidity, available fuels, exhaust gas outlets.

viii) Economics - the cost of dryer and drying.

ix) Other parameters - maintenance, safety, etc.

\section{B. Material Selection}

The material selection is depending on the climatic conditions and the availability of the material at that location. Most of the dryers are built by using a steel frame. For a low-cost dryer, Mild Steel is used or sometimes wood, plastic, or PVC pipes can be used. The cost of the dryer depends on the application product. What type of product quality needed to be based on that the product cost and material are selected?

\section{How to Predict the Moisture Content}

Moisture in the food items needs to remove but how much that is the question arises. Before removing what is the amount of moisture present in the item to the dryer is to be known. Measuring moisture content allows controlling the drying process. This helps to dryer the product to a specific level of moisture content rather than for a fixed period. Following are the methods of finding the moisture content [18].

1. Moisture content can be predicted by measuring the weight of the product before and after drying.

2. Electrical resistance type meters operate on the principle of electrical resistance, which varies minutely by the moisture content of the item measured. Resistance meters have an average accuracy of $+1 \%$ MC over their operating range.

3. Dielectric moisture meters rely on surface contact with a flat plate electrode that does not penetrate the wood. Similar to resistance meters, the accuracy of dielectric meters in measuring average $\mathrm{MC}$ is $+1 \%$ moisture content. 


\section{International Journal of Innovations in Engineering and Science, www.ijies.net}

4. The Modern portable moisture balances are available with built-in infrared heaters, which directly measure the moisture content of the product and gives a profile of moisture content variations with time.

5. The advanced method of measuring the moisture content is Radio Frequency Capacitance method. The instrument measures the loss, or change, in RF dielectric constant as affected by the presence of moisture.

6. By Mathematical calculation.

Determine the moisture content of the test

1. Mass of water in sample $=$ wet mass minus the dry mass

2. Percent moisture $=($ Mass of Water $/$ Dry Mass of Sample) $* 100$

For example

If the throughput of the dryer is $50 \mathrm{~kg}$ of wet product per hour, drying it from $65 \%$ moisture to

$20 \%$ moisture, the heat requirement is:

$50 \mathrm{~kg}$ of wet product contains $50 \times 0.65 \mathrm{~kg}$ water $=32.5$ or $33 \mathrm{~kg}$ moisture and

$50 \times(1-0.65)=17.5 \mathrm{~kg}$ bone-dry product.

As the final product contains $20 \%$ moisture, the moisture in the product is $17.5 / 9=2 \mathrm{~kg}$ and so

Moisture removed $=(33-2)=31 \mathrm{~kg}$

Latent heat of evaporation $=2257 \mathrm{~kJ} \mathrm{~kg}-1\left(\right.$ at $100{ }^{\circ} \mathrm{C}$ so heat necessary to supply $=31 \times 2257=6.9 \times 10^{4} \mathrm{~kJ}$

\section{Dryer Application for Household}

The application of solar dryers is not limited; it has vast applications. The major application area is in agricultural and agro-industries. To form a powder of the product with less moisture dryer is used. A product like pepper, turmeric, chilies, coriander, dehydration of fruits and vegetables like mango, sapota, grapes, banana, papaya amla, carrot, beetroot, potato, bitter gourd, and many more. It is also useful in many medicine preparations by drying herbs like tulsi, neem cashew, paddy, mushroom, tea leaves, coffee beans, marine food, tobacco, wheat, seeds, wood, and many more [1-10].

The dryer is not only used for drying foods but is also used for drying clothes, producing the greenhouse effect. Forgiving the cold and warm air to the plants. Then warming the building or providing the hot air to the building or industries [11-15].

Another application of solar dryers is for dairy farming and livestock. For fulfilling the need for water and heating, pig and poultry farms raise animals in enclosed buildings. For animal husbandry, it is necessary to provide the proper temperature of the air in winters with better air quality to maximize the health and growth of the animals.

The dryer can also be used in drying household items like pickles, lemon, papad, potatoes, bananas, serial dryings like wheat, jawar, rice, and many more. Some it is needed to remove the insect from serials and other items. A dryer can help in removing the insects directly without keeping the items in open sun drying and maintain quality and hygiene [14].

\section{III- CONCLUSION}

Open sun drying is not a valid and hygienic technique for drying food, marine agriculture, and non-agriculture products. Solar drying is the new method of open sun drying and its scope is not limited to drying but also to supplying the hot air. The rate of the drying depends on the volume of the solar dryer, airflow rate, moisture content in the item, humidity in the air as per the environment conditions, and of course the average amount of solar radiation available during the drying season. The dryer has a huge scope in drying the products and providing hot air to many areas of application.

\section{REFERENCES}

[1] El-Sebaii A, Shalaby S. Solar Drying of Agricultural Products: A Review. Renew Sustain Energy Rev 2012;16:37-43. https://Doi.Org/10.1016/J.Rser.2011.07.134.

[2] Belessiotis V, Delyannis E. Solar Drying. Sol Energy 2011;85:1665-91. https://Doi.Org/10.1016/J.Solener.2009.10.001.

[3] M. R. Nukulwar and V. B. Tungikar, A Review on Performance Evaluation of Solar Dryer and its Material For Drying Agricultural Products, Materials Today: Proceedings, https://Doi.Org/10.1016/J.Matpr.2020.08.354.

[4] Abhay Bhanudas Lingayata, V.P. Chandramohana, V.R.K. Rajua, Venkatesh Meda, A Review on Indirect Type Solar Dryers for Agricultural Crops - Dryer Setup, its Performance, Energy Storage And Important Highlights, Applied Energy 258 (2020) 114005, https://Doi.Org/10.1016/J.Apenergy.2019.114005 . 


\section{International Journal of Innovations in Engineering and Science, www.ijies.net}

[5] Hajar Essalhi, Rachid Tadili, M.N Bargach, Conception of A Solar Air Collector For An Indirect Solar Dryer Pear Drying Test. $4^{\text {th }}$ Intern

[6] ational Conference on Power and Energy Systems Engineering, Cpese 2017, 25- 29 September 2017, Berlin, Germany, Energy Procedia 141 (2017) 29-33, Doi; 10.1016/J.Egypro.2017.11.114

[7] I.D.Paul, Dr. A.M.Vaidya, A Review on The Classifications of Solar Dryers, Proc. Xii Ipromm-2016 (Challenges In Manufacturing) Vnit Nagpur, 22-23 December 2016

[8] Pradeep Kumar, Dheerandra Singh, Advanced Technologies and Performance Investigations of Solar Dryers: A Review, Renewable Energy Focus Volume 35, December 2020, $\quad p p$ - 148-158, Https://Doi.Org/10.1016/J.Ref.2020.10.003.

[9] S. Nabnean A, P. Nimnuan, Experimental Performance of Direct Forced Convection Household Solar Dryer For Drying Banana, Case Studies In Thermal Engineering 22 (2020) 100787. Https://Doi.Org/10.1016/J.Csite.2020.100787.

[10] El- Amin Omda Mohamed Akoy A, Mohamed Ayoub Ismail B, El-Fadil Adam Ahmed C And W. Luecke D., Design And Construction Of A Solar Dryer For Mango Slices, Conference: Tropentag 2006 Prosperity \& Poverty In A Globalized World: Challenges For Agricultural Research. Bonn, Germany, October 11-13, 2006.

[11] Izhak Devid Paul \& Dr. Adwait Manoharrao Vaidya, Design Of Solar Dryer, Journal Of Shanghai Jiaotong University, Volume 16, Issue 11, November-2020, Pp79-92.

[12] R. Vidya Sagar Raju, R. Meenakshi Reddy, E. Siva Reddy, Design and Fabrication of Efficient Solar Dryer, Int. Journal Of Engineering Research And Applications, Vol. 3, Issue 6, Nov-Dec 2013, Pp.1445-1458.

[13] M.C. Ndukwu, D. Onyenwigwe, F.I. Abam, A.B. Eke, Dirioha C, Development of A Low-Cost Wind-Powered Active Solar Dryer Integrated With Glycerol As Thermal Storage, Renewable Energy (2020), https://Doi.Org/10.1016/J.Renene.2020.03.016..

[14] Prof. Pravin M. Gupta, Amit S. Das, Ranjit C. Barai, Sagar C. Pusadkar, Vishal G. Pawar, Design And Construction of Solar Dryer For Drying Agricultural Products, International Research Journal of Engineering And Technology (IRJET), Volume: 04 Issue: 03 | Mar 2017, Pp-1946-1951.

[15] Izhak Devid Paul1, Dr.A.M.Vaidya, Scope of Solar Dryer, GIS Science Journal, Volume 7, Issue 7, 2020, Pp-159-166.

[16] Om Prakash A,N, Vinodlaguri A, Anukulpandey B, Anilkumar C,D, Arbindkumar, Review On Various Modelling Techniques For The Solar Dryers, Renewable and sustainable energy reviews 62 (2016) pp-396-417, http://Dx.Doi.Org/10.1016/J.Rser.2016.04.028.
[17] Mahesh Kumar N, Sunilkumar sansaniwal, Pankaj khatak, Progress In Solar Dryers For Drying Various Commodities, Renewable and sustainable energy reviews, $55 \quad$ (2016) pp-346-360, http://Dx.Doi.Org/10.1016/J.Rser.2015.10.158.

[18] Visavale, G.L., Principles, Classification and Selection of Solar Dryers. In Solar Drying: Fundamentals, Applications And Innovations, Ed. Hii, C.L., Ong, S.P., Jangam, S.V. And Mujumdar, A.S., 2012, ISBN - 978981 - 07- 3336- 0, Published In Singapore, pp. 1 - 50.

[19] Arun S .Mujumdar, Handbook Of Industrial Drying, Revised And Expanded, Volume 1 Second Edition, CRC Press Taylor And Francis Group,. 